\title{
COVID-19 in Rajasthan: Status and Effects of Containment Measures
}

\author{
Ravi Prakash Sharma' ${ }^{1}$, Jyoti Gupta ${ }^{1}$, Kusum Lata Gaur ${ }^{2}$, Deepa Meena ${ }^{1, *}$, Praveen Aswal ${ }^{1}$, KK Sharma ${ }^{1}$, Ruchi \\ Singh ${ }^{1}$, Raman Sharma ${ }^{2}$, Bharti Malhotra ${ }^{2}$, Disha Meena ${ }^{3}$
}

\section{Ravi Prakash Sharma', Jyoti Gupta' ${ }^{1}$, Kusum Lata Gaur $^{2}$, Deepa Meena ${ }^{1, *}$, Praveen Aswal', KK Sharma ${ }^{1}$, Ruchi Singh ${ }^{1}$, Raman Sharma², Bharti Malhotra², Disha Meena ${ }^{3}$}

\section{'Directorate of Medical and Health Services, Jaipur, Rajasthan, INDIA. ${ }^{2}$ Department of Community Medicine, SMS Medical College, Jaipur, Rajasthan, INDIA. \\ ${ }^{3}$ Department of Microbiology, SMS Medical College Jaipur, Rajasthan, INDIA. \\ ${ }^{4}$ Regional Office for Health and Family Welfare, Jaipur, Rajasthan, INDIA.}

\section{Correspondence}

Dr. Deepa Meena,

State Epidemiologist (IDSP) Rajasthan,

Directorate of Medical and Health

Services, Jaipur, Rajasthan, INDIA.

Mobile no: +91 7877815995

Email: deepa_mn0211@yahoo.co.in

History

- Submission Date: 13-07-2020

- Revised Date: 14-08-2020

- Accepted Date: 18-09-2020

DOI : 10.5530/ijmedph.2020.4.43

Article Available online

http://www.ijmedph.org/v10/i4

\section{Copyright}

(C) 2020 Phcog.Net. This is an openaccess article distributed under the terms of the Creative Commons Attribution 4.0 International license.

\begin{abstract}
Background and Objectives: Presently world is facing Corona virus disease pandemic. This disease was first identified in Wuhan city of China which spread rapidly to more than 200 countries including India. Rajasthan is a state affected badly with this disease. So this present study was conducted to find out the status of COVID-19 in state and to find out the effects of containment measures taken. Materials and Methods: This record base case series type of study was conducted from reports received of confirmed COVID-19 cases and reported to the IDSP, DMHS from March 2nd 2020 to May 25th 2020, from various reporting units of Rajasthan. Desired information's were collected, compiled and analyzed. Interpretation and Conclusion: There were 7351 laboratory-confirmed case including 4061 recovered cases and 166 deaths. Recovery rate and Case Fatality Rate were found $55.24 \%$ and $2.26 \%$ respectively. $(2.4 \%)$ reported. Although patients of all ages were affected with this disease but majority $(81.99 \%)$ were in 16-60 years of age group. In these positive cases male predominance was also observed with M:F ratio 2.11. Majority of district of Rajasthan were affected with this pandemic having about half of cases in three districts v.i.z. in Jaipur, Jodhpur and Udaipur districts. Average Doubling time has increased from 4 days to 18 days as a result of containment measures undertaken in Rajasthan. So these containment measures like social distancing, masking, washing hand frequently etc. Should be taken care of even after lockdown to prevent the COVID-19 infection.

Key words: COVID-19, PHEIC, SARS CoV-2, Lockdown, Containment Measures, Effect of Lockdown.
\end{abstract}

\section{INTRODUCTION}

On $12^{\text {th }}$ December 2019, cases of pneumonia of unknown cause were identified in Wuhan, Hubei Province of China. On 31 December 2019, the WHO China Country Office was informed of cases of pneumonia of unknown etiology (unknown cause) detected in Wuhan City, Hubei Province of China. ${ }^{1}$ On 07.01.20 causative agent of this disease was identified as severe Acute Respiratory Syndrome Corona Virus 2 (SARS-CoV-2). ${ }^{2}$

On 13 January 20, first time a COVID-19 case was identified outside China in Thailand. ${ }^{1}$ On $30^{\text {th }}$ January 20 there were 9700 cases worldwide spreading in 21 countries including India. WHO declared it as Public Health Emergency of International concern (PHEIC) on $30^{\text {th }}$ January 2020. ${ }^{1}$ On $11^{\text {th }}$ March 20, WHO officials declared its a pandemic with 118,000 cases and 4,291 death spread over to 114 countries. ${ }^{1}$ First case of COVID-19 was reported in India on $30^{\text {th }}$ January 20 who was a student came from China ${ }^{3}$ and first confirmed cases on $2^{\text {nd }}$ March 20 in Jaipur a Italian tourist. ${ }^{4}$ As of 9 July 2020, there were 767,296 cases and 21,129 deaths in the country being highest number of cases in $\mathrm{Asia}^{5}$ and third highest number

of confirmed cases in the world after United States and Brazil..$^{5}$

With the emergence of COVID case in Bundi on $28^{\text {th }}$ May 20, 33 districts of Rajasthan are affected with this epidemic. ${ }^{6}$ As per Ministry of Health and Welfare Government of India declared that on 10 July 2020, there are 22563 cases and 491 deaths in the Rajasthan being tenth in country.

Rajasthan government has taken multiple measures to combat to the situation along with following the containment measures suggested by Indian Government. So this record based descriptive study was conducted to find out the status of COVID-19 in state along with to find out the effects of preventive measures taken by the government.

\section{MATERIALS AND METHODS}

This record based descriptive analytic study was conducted in Directorate of Medical and Health Services (DMHS) in collaboration of Directorate of Medical Education (DME) in year 2020.

For this study all the reports regarding laboratoryconfirmed COVID-19 cases were taken since 
starting ( $2^{\text {nd }}$ March 20) to $25^{\text {th }}$ May 2020. These reports were retrieved from the department of Integrated Disease Surveillance Programmed (IDSP) of DMHS and from DME.

Beside number of cases and information regarding age, sex, residence of positive case, present status of cases was found. Desired information's were collected and compiled in Microsoft Excel 10 workbook sheet. These data were classified presented in the form of tables and charts and analyzed to get inferences.

Steps (main ones) taken by Rajasthan Government to combat the COVID-19 were as follows:-

- After having a meeting on $3^{\text {rd }}$ March 20 with Union Health Ministry after having 2 positive cases positive in Jaipur, the Chief Minister of Rajasthan ordered to sanitize the hotels where the Italian tourists resided. ${ }^{6}$

- On 18 March, after getting three people of a family tested positive for COVID-19 in Jhunjhunu, movement was restricted within $1 \mathrm{~km}^{2}$ of their residence. ${ }^{6}$

- On $19^{\text {th }}$ March, the state government imposed Section 144 across the entire state to restricted gathering of five or more. ${ }^{7}$ The government had also screened all passengers reaching Jaipur via foreign flights and kept the ones showing symptoms in home isolation for 14 days. ${ }^{6}$

- On $20^{\text {th }}$ March after getting cases in Bhilwara, the government imposed a curfew on the whole district and sealed its borders. Door-to-door survey of around 80,000 houses in the Bhilwara city was initiated. ${ }^{6}$

- On $22^{\text {nd }}$ March, the state was first to announce complete lockdown starting 22 March, barring essential services. ${ }^{6}$

- On 22 March, it banned public transport services in the state. ${ }^{6}$

- Rajasthan also followed the India's launch of a $14 \mathrm{hr}$ voluntary 'Janta Curfew' and immediately after that on $22^{\text {nd }}$ March 2020 for 21 days which was extended upto $30^{\text {th }}$ May 2020 in two phases. After that now unlocking process has started from $1^{\text {st }}$ June 2020 with the opening of religious places, hotels, restaurants and other hospitality services, shopping malls from $8^{\text {th }}$ June 20 in its first phase. With this unlocking public became reluctant to go full-on into the prelockdown life. ${ }^{8-12}$

- On 24 March, the state banned all private vehicles in the roads after COVID-19 cases crossed 32 in the state. ${ }^{6}$ The state government had also announced free ration for two months for families covered under the National Food Security Act (NFSA). ${ }^{6}$

- On 26 March, after getting a positive case in Ramganj, Ramganj was put under a curfew as it became a new hotspot in the state. Door-todoor screening was started. ${ }^{6}$

- On 18 May, Rajasthan government issued guidelines for relaxations like movement of individuals were restricted from $7 \mathrm{pm}$ to $7 \mathrm{am}$ for non-essential activities, all shops including malls except those in containment zones were allowed to open, with conditions of social distancing and only two to five customers allowed at a time. ${ }^{6}$

\section{Monitoring and supervision of containment measures}

Thirty three districts of state were divided into 7 zones administratively so for each district and zone respectively nodal officer for COVID-19 was designated who is responsible for monitoring and supervising antiCOVID-19 activities of district. At State and district level War rooms were constituted for prevention, containment and management of COVID -19 through a graded, pre-emptive and proactive approach. These are being regularly reviewed and monitored at the highest level.

To find out the effects of containment measures specially of lockdown, the whole period was divided into:
1. Before Lockdown (before 25.03.2020)

2. Lockdown 1.0 (Between 25.03.2020 to 14.04.2020)

3. Lockdown 2.0 (Between 14.04.2020 to 03.05.2020)

4. Lockdown 3.0 (Between 03.05.2020 to 17.05.2020)

5. Lockdown 4.0 (Between 17.05.2020 to 25.05.2020) (although this lockdown was continue till 31.05 .2020 but study was conducted upto 25.05.2020 only)

All the variables like case fatality rate, doubling time of cases etc were analyzed as per these above periods and compared to find out the effect of lockdown.

\section{Statistical Analysis}

Qualitative data were expressed in percentage and proportions and quantitative data were expressed in mean and standard deviation. Epidemic curves was constructed with date wise data available. Growth rate, Doubling Time, Case fatality rate etc for COVID-19 were also calculated.

\section{RESULTS}

By $25^{\text {th }}$ May 2020, total 7351 cases were found COVID-19 positive in Rajasthan. Out of these 7351 cases, 4061 were recovered and 166 cases were died due to COVID-19; calculating recovery rate $55.24 \%$ and case fatality rate $2.26 \%$. (Figure 1 )

As per sex wise distribution of cases, majority (67.9\%) of cases were male having M:F ratio 2.11 and majority were in age group 16-30 years (38.06\%) followed by $31-45$ years $(27.71 \%)$, 46-60 years $(16.22 \%)$, less than 16 years $(10.6 \%)$ and more than 60 years age group $(7.41 \%)$. People who move outside house $16-60$ years were $81.99 \%$. (Figure 2 and 3 )

When district wise distribution of cases were analyzed, it was found that maximum cases were in Jaipur (1807 i.e. $24.58 \%$ ) followed by Jodhpur (1213 i.e. 16.5\%), Udaipur (499 i.e. 6.9\%), Nagaur (404 i.e. 5.5\%), Kota (387 i.e. $5.26 \%$ ), Pali (349 i.e. $4.75 \%$ ) etc. (Figure 4 )

Epidemic curve was constructed of these 7351 cases, cases were increasing with the time. More than 100 case per day first time came on 11.04.2020, 200 cases crossed on 13.05.2020 and cases crossed over 300 on $24^{\text {th }}$ May 2020 . That shows its faster growth with time, which was better depicted in Table 1 and Figure 5.

Status of COVID-19 cases as per status of lockdown were observed to found the effect of lockdowns. It was observed that although the number of cases were regularly increasing with the time but doubling time of cases has increased from 4 days to 18 days in $3^{\text {rd }}$ lockdown which again become 17 days in $4^{\text {th }}$ lockdown. Likewise average growth rate also

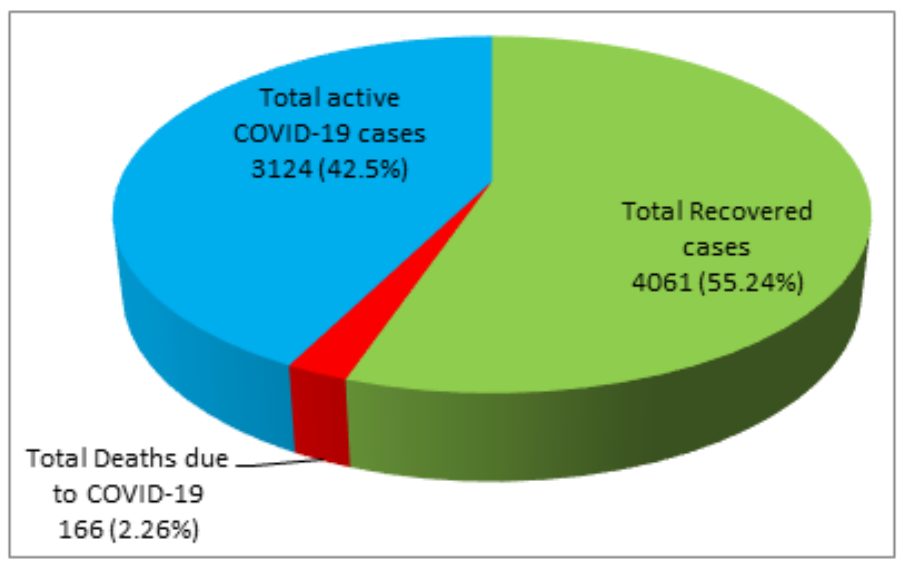

Figure 1: Status of COVID-19 cases as on $25^{\text {th }}$ May $2020(N=7351)$. 
Table 1: Status of COVID-19 cases as per status of lockdown.

\begin{tabular}{|c|c|c|c|c|c|}
\hline Variables & $\begin{array}{c}\text { Before Lockdown } \\
(24.03 .2020)\end{array}$ & $\begin{array}{c}2^{\text {nd }} \text { Lockdown } \\
15.04 .2020 \text { to } \\
03.05 .2020\end{array}$ & $\begin{array}{c}2^{\text {nd }} \text { Lockdown } \\
15.04 .2020 \text { to } \\
03.05 .2020\end{array}$ & $\begin{array}{c}3^{\text {rd }} \text { Lockdown 03- } \\
17.05 .2020\end{array}$ & $\begin{array}{c}4^{\text {th }} \text { Lockdown 18- } \\
25.05 .2020\end{array}$ \\
\hline $\begin{array}{l}\text { Average New } \\
\text { Positive/Day }\end{array}$ & 9 & 69.67 & 104.05 & 161.43 & 258.63 \\
\hline Total Cases Till Date & 52 & 1045 & 3022 & 5282 & 7351 \\
\hline Increase in cases & 52 & 993 & 1977 & 2260 & 2069 \\
\hline $\begin{array}{c}\text { Total recovered Till } \\
\text { date }\end{array}$ & 0 & 214 & 1663 & 3103 & 4061 \\
\hline $\begin{array}{c}\text { Increase in Recovered } \\
\text { cases }\end{array}$ & 0 & 214 & 1449 & 1440 & 958 \\
\hline Total Death Till date & 1 & 10 & 77 & 132 & 166 \\
\hline Increase in deaths & 1 & 9 & 67 & 55 & 34 \\
\hline $\begin{array}{c}\text { Average Recovery } \\
\text { Rate }\end{array}$ & 0 & 16.00 & 35.00 & 58.00 & 57.30 \\
\hline Average Death Rate & 1.92 & 1.50 & 1.70 & 2.70 & 2.40 \\
\hline Average Growth Rate & 24.3 & 17.30 & 5.80 & 4.10 & 4.20 \\
\hline Doubling time & 4 & 6 & 10 & 18 & 17 \\
\hline
\end{tabular}

Table 2: Comparison of variables related to status of COVID-19 as per status of lockdown.

\begin{tabular}{|c|c|c|c|c|}
\hline Variablesz & $\begin{array}{l}\text { Average } \\
\text { Recovery } \\
\text { Rate }\end{array}$ & $\begin{array}{l}\text { Average } \\
\text { Death } \\
\text { Rate }\end{array}$ & $\begin{array}{l}\text { Average } \\
\text { Growth } \\
\text { Rate }\end{array}$ & $\begin{array}{l}\text { Doubling } \\
\text { Time }\end{array}$ \\
\hline $\begin{array}{c}\text { Before Lockdown } \\
(24.03 .2020)\end{array}$ & 0 & 1.9 & 24.3 & 4 \\
\hline $\begin{array}{c}\text { First Lockdown } \\
25.03 .20 \text { to } 14.04 .2020\end{array}$ & 16 & 1.5 & 17.3 & 6 \\
\hline $2^{\text {nd }}$ Lockdown & & & & \\
\hline $\begin{array}{c}15.04 .2020 \text { to } \\
03.05 .2020\end{array}$ & 35 & 1.7 & 5.8 & 10 \\
\hline $\begin{array}{l}3^{\text {rd }} \text { Lockdown } \\
03-17.05 .2020\end{array}$ & 58 & 2.7 & 4.1 & 18 \\
\hline $\begin{array}{l}4^{\text {th }} \text { Lockdown } \\
18-25.05 .2020\end{array}$ & 57.3 & 2.4 & 4.2 & 17 \\
\hline$P$ Value (LS) & $<0.001(\mathrm{~S})$ & $0.037(S)$ & $<0.001(\mathrm{~S})$ & $<0.001(\mathrm{~S})$ \\
\hline
\end{tabular}

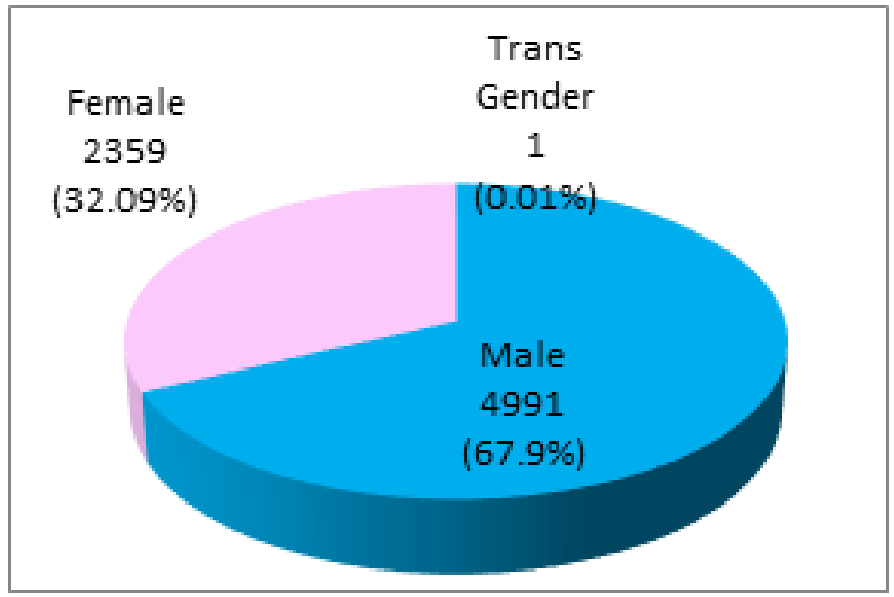

Figure 2: Sex wise distribution of cases ( $N=7351)$.

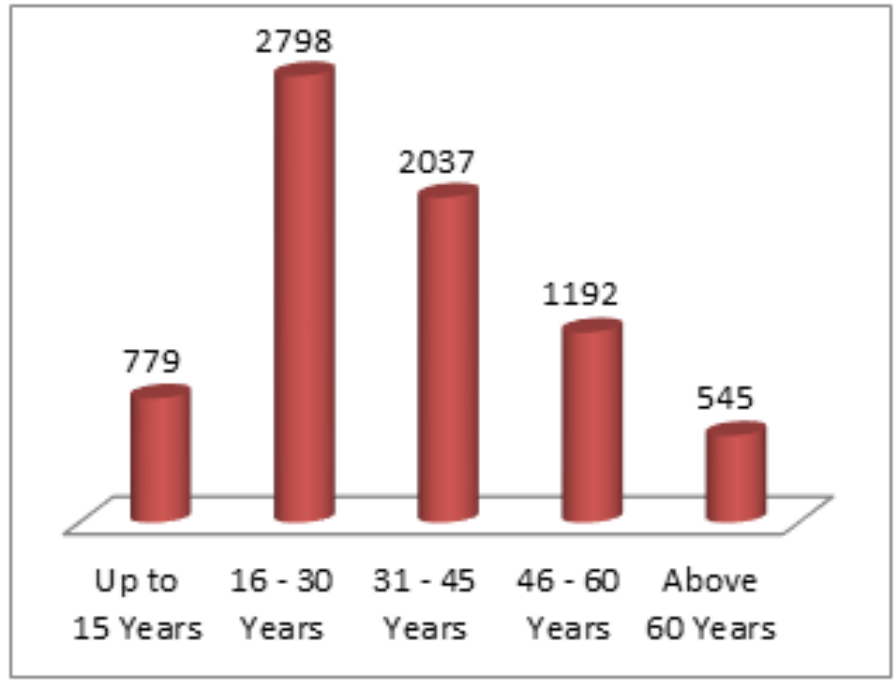

Figure 3: Age wise distribution of cases ( $N=7351)$

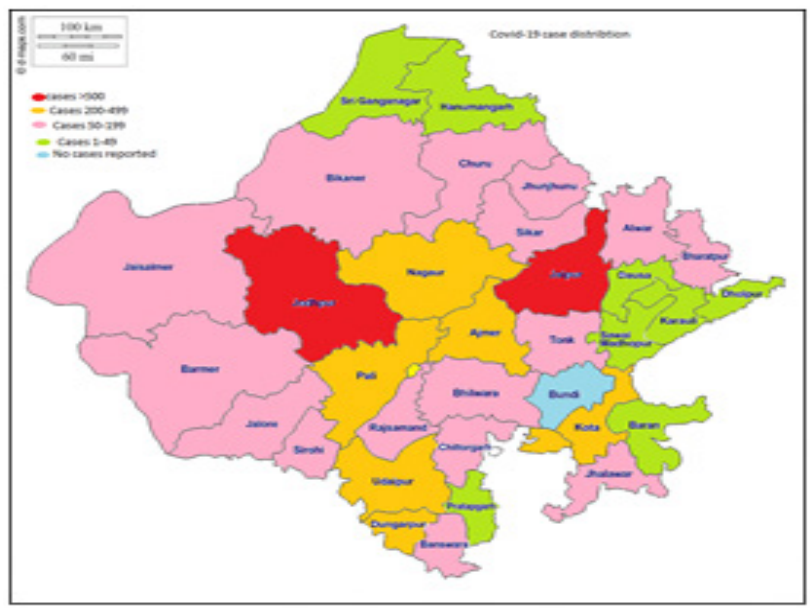

Figure 4: District wise distribution of COVID-19 cases ( $N=7351)$. 


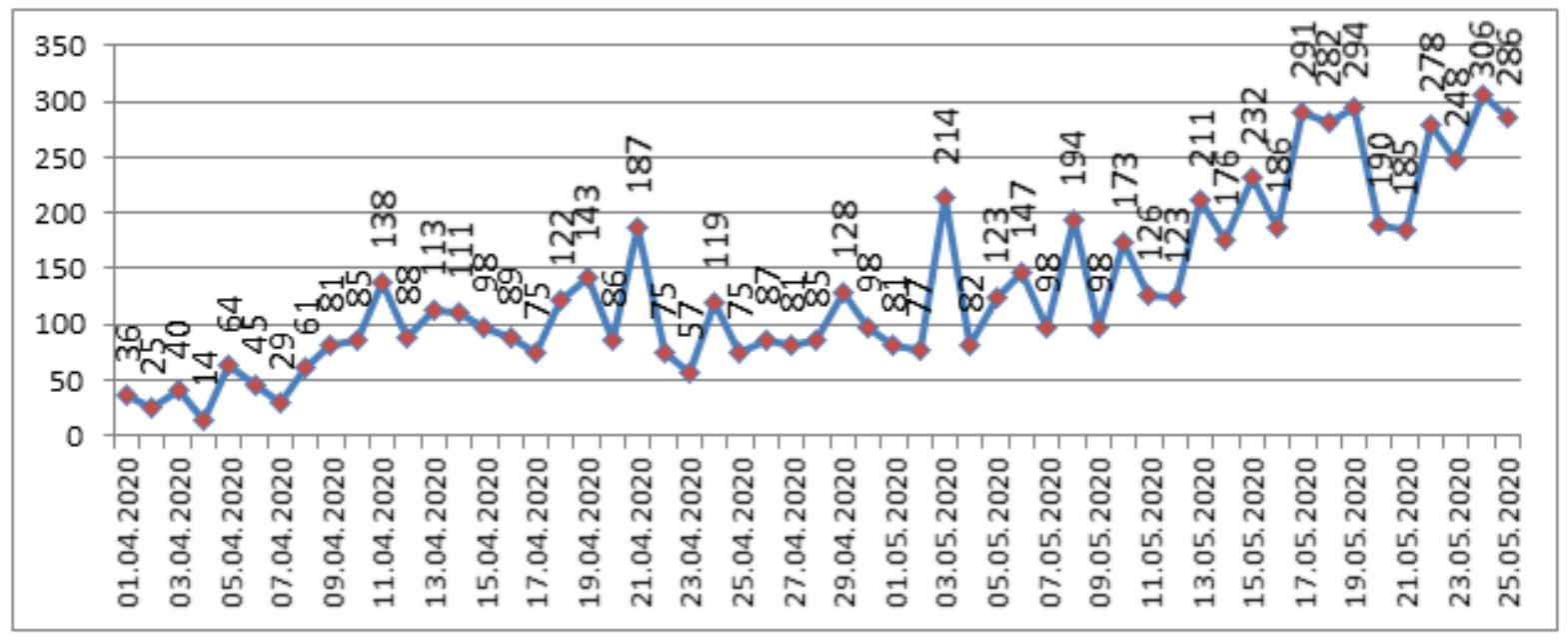

Figure 5: Date wise new $n$ Covid cases ( $N=7351)$. (before $1^{\text {st }}$ April 115 cases).

decreased $24.3 \%$ to $4.1 \%$ in $3^{\text {rd }}$ lockdown which again become $4.2 \%$ in $4^{\text {th }}$ lockdown. Although average death rate is increasing with time and ranges from 1.95 to $2.7 \%$ but average recovery rate also has significantly increased from baseline (before lockdown); it increases from $0 \%$ to $58 \%$ till $3^{\text {rd }}$ lockdown which again start decreasing and become $57 \%$. (Table 1 and 2).

\section{DISCUSSION}

In this present study, on $25^{\text {th }}$ May 2020, there were 7351 laboratoryconfirmed case including 4061 recovered cases and 166 deaths calculating Recovery rate (RR) $55.24 \%$ and Case Fatality Rate (CFR) $2.26 \%$. Case fatality rate was found lesser than that of reported by other authors. ${ }^{13-20}$ whether in-house or in other countries. Most of studies were conducted in China like $\mathrm{Wu} \mathrm{Z}$ et al. ${ }^{13}$ reported case fatality rate $2.3 \%$ with $14.8 \%$ in the above 80 years population in China. Other study conducted by Chen $\mathrm{N}$ et al. ${ }^{14}$ in Wuhan city of China reported CFR $2.5 \%$ and $8.0 \%$ of population in the 70-79 years. Another study conducted bu Tuo Ji et al. ${ }^{15}$ in Huangshi city of C found CFR 3.74\%. Even in Italy the CFR is reported more than the present study. ${ }^{16}$ Studies ${ }^{17-20}$ conducted in India are very few but they have also reported CFR more than the present study. Basu D et al. ${ }^{17}$ found CFR 3.5\% in their study. Mazumder A et al. ${ }^{18}$ conducted a study on 1161 COVID patients and reported that 29 deaths and 94 patients recovered cases calculating CFR 2.5\% and Recovery rate $8.1 \%$. This recovery rate was also significantly lower than the present study (8.1\% v/s 55.24\%). This lowered CFR and higher RR in present study be because of betterment of medical facilities and better understanding of epidemiology of COVID-19 disease virus.

In the present study, although patients of all ages were affected with this disease but majority (81.99\%) were in 16-60 years of age group. In these positive cases male predominance was also observed with M:F ratio 2.11 in present study. Other studies of India and other countries also reported almost similar observations regarding age and sex affected due to this disease. Mazumder A et al. ${ }^{18}$ reported median age 38 years with M:F ratio 2.78 and 20-39 year-old males being the most affected group. Gupta $\mathrm{N}$ et al. ${ }^{19}$ reported median age 54 years with interquartile range: 44-63 and M:F ratio of 4. Tuo Ji et al. ${ }^{15}$ reported age range 1 month to 92 years and M:F ratio 1.1 and maximum cases $(79.11 \%)$ in age group of 18-64 years. Studies conducted in Wuhan, China ${ }^{14,21,22}$ cohorts of Wuhan, the median age of affected patients ranges from 49-56 years.

In present study effect of lockdown was clearly observed by significant increase in doubling time and decrease in growth rate. Doubling time of cases has increased from 4 days to 18 days in $3^{\text {rd }}$ lockdown which again become 17 days in $4^{\text {th }}$ lockdown. Likewise average growth rate also decreased $24.3 \%$ to $4.1 \%$ in $3^{\text {rd }}$ lockdown which again become $4.2 \%$ in $4^{\text {th }}$ lockdown. Studies in India and abroad also reported positive impact of lockdown as in this present study. Basu D et al. ${ }^{17}$ observed that doubling time has increased from about 5 days to over 10 days at the middle of May 20. Arun Mitra et al. ${ }^{23}$ Gupta $\mathrm{N}$ et al..$^{19}$ Gupta $\mathrm{M}$ et al. ${ }^{20}$ also reported increase in doubling time after lockdown and concluded that it is muchneeded effort to delay the peak flatten the epidemic-curve. Similar observations were from foreign authors. ${ }^{15,24,25}$

\section{CONCLUSION}

All the age are susceptible for COVID-19 with M:F ratio 2.11. Majority (81.99\%) of cases were in 16-60 years of age, who move outside. Majority of district of Rajasthan were affected with this pandemic having about half of cases in three districts viz in Jaipur, Jodhpur and Udaipur districts. Case Fatality Rate was found $2.26 \%$ and Recovery rate was found $55.24 \%$. Average Doubling time has increased from 4 days to 18 days as a result of containment measures undertaken in Rajasthan. So these containment measures like social distancing, masking, washing hand frequently etc. should be taken care of even after lockdown to prevent the COVID-19 infection.

\section{ACKNOWLEDGEMENT}

The authors would like to acknowledge the support of the following: Mr Akhil Arora PHS (M\&H), Mr. Naresh Thakral Special Secretary and $\mathrm{MD}(\mathrm{NHM})$.

\section{CONFLICT OF INTEREST}

The authors declare no Conflict of interest.

\section{REFERENCES}

1. https://www.who.int/emergencies/diseases/novel-coronavirus-2019/events-asthey-happen

2. Naming the coronavirus disease (COVID-19) and the virus that causes it. World Health Organization (WHO). 2020.

3. Home. Ministry of Health and Family Welfare. GOI. https://www.mohfw.gov.in/ (Retrieved 9 July 2020)

4. Italian tourist tests positive for coronavirus in Rajasthan, samples sent to Pune for confirmation. https://www.newindianexpress.com/nation/2020/mar/02/ italian-tourist-tests-positive-for-coronavirus-in-rajasthan-samples-sent-to-punefor-confirmation-2111164.htm

5. Deepankar B, Maxwell S, Mike K, Soumik P, Rupam B, Bhramar M. Lockdown 
Effect on COVID-19 Spread in India: National Data Masking State-Level Trends. Med Rxiv Preprint doi: https://doi.org/10.1101/2020.05.25.20113043

6. http://www.rajswasthya.nic.in/Corona\%20Virus.htm

7. Official Updates Coronavirus - COVID-19 in India https://www.mygov.in/covid-19

8. Regan H, Mitra E, Gupta S. India places millions under lockdown to fight coronavirus. CNN. 2020

9. PM Modi announces extension of lockdown till 3 May. Livemint. 2020.

10. Lockdown extended till 17 May: What will open, remain closed. Livemint. 2020. Retrieved 14 May 2020

11. Coronavirus lockdown extended till 31 May, says NDMA. Livemint. 2020. Retrieved 17 May 2020

12. Explain Speaking: As Unlock enters third week, a visible lack of public confidence. 2020. https://indianexpress.com/article/explained/explainspeakingunlock-lack-of-public-confidence-6459195/

13. Wu Z, McGoogan JM. Characteristics of and Important Lessons from the Coronavirus Disease 2019 (COVID-19) Outbreak in China: Summary of a Report of 72314 Cases from the Chinese Center for Disease Control and Prevention. JAMA. 2020

14. Chen N, Zhou M, Dong X, et al. Epidemiological and clinical characteristics of 99 cases of 2019 novel coronavirus pneumonia in Wuhan, China: A descriptive study. Lancet. 2020;395(10223):507-13.

15. Tuo J, Hai-Lian C, Jing $X$, Ling-Ning W, Jie-Jia L, Kai C, et al. Lockdown contained the spread of 2019 novel coronavirus disease in Huangshi city, China: Early epidemiological findings. Clinical Infectious Diseases. Ciaa 390. https:// doi.org/10.1093/cid/ciaa390

16. Livingston E, Bucher K. Coronavirus Disease 2019 (COVI-19) in Italy. JAMA.
2020;323(14): 1335 .

17. Deepankar B, Maxwell S, Mike K, Soumik P, Rupam B, Bhramar M. Lockdown Effect on COVID-19 Spread in India: National Data Masking State-Level Trends Med Rxiv Preprint doi: https://doi.org/10.1101/2020.05.25.20113043

18. Mazumder A, Arora M, Bharadiya V, et al. SARS-CoV-2 epidemic in India: epidemiological features and in silico analysis of the effect of interventions. F1000 Research. 2020;9:315. [version 2; peer review: 2 approved]. (https:// doi.org/10.12688/f1000research.23496.2)

19. Gupta N, Praharaj I, Bhatnagar $T$, et al. Severe acute respiratory illness surveillance for coronavirus disease 2019, India, 2020. Indian J Med Res. 2020

20. Gupta M, Mohanta SS, Rao A, et al. Transmission dynamics of the COVID-19 epidemic in India and modelling optimal lockdown exit strategies. Med Rxiv. 2020

21. Guan WJ, Ni ZY, HuY, et al. Clinical Characteristics of Coronavirus Disease 2019 in China. N Engl J Med. 2020

22. Huang C, Wang Y, Li X, et al. Clinical features of patients infected with 2019 novel coronavirus in Wuhan, China. Lancet. 2020;395(10223):497-506.

23. Arun M, Abhijit PP, Adrija R, Ankur J. Impact of COVID-19 epidemic curtailment strategies in seleced Indian states an analysis by reproduction number and doubling time with incidence modelling. Med Rxiv preprint. 2020. https://doi.or g/10.1101/2020.05.10.20094946doi [accessed Jul 11 2020].

24. Lau H, Khosrawipour V, Kocbach P, Mikolajczyk A, Schubert J, Bania J, et al. The positive impact of lockdown in Wuhan on containing the COVID-19 outbreak in China. J Travel Med. 2020;27(3):taaa037.

25. Lee VJ, Chiew CJ, Khong WX. Interrupting transmission of COVID-19: lessons from containment efforts in Singapore. JTravel Med. 2020.

Cite this article : Sharma RP, Gupta J, Gaur KL, Meena D, Aswal P, Sharma KK, Singh R, Sharma R, Malhotra B, Meena D. COVID-19 in Rajasthan: Status and Effects of Containment Measures. Int J Med Public Health. 2020;10(4):202-6. 